\title{
POST HARVEST MANAGEMENT OF POTATO (SOLANUM TUBEROSUM L.) IN SUB-TROPICAL ZONE OF JAMMU DIVISION
}

\author{
Quadri Javeed Ahmad Peer ${ }^{1 *}$, Haroon Rashid ${ }^{2}$, Sheikh Muzaffar Ahmad ${ }^{3}$ \\ AND MH CHESTI ${ }^{4}$ \\ Division of Extension Education, Faculty of Agriculture, Wadura campus, Sher-E-Kashmir \\ University of Agricultural Sciences and Technology of Kashmir, India
}

Key words: Post harvest management, Physiological disorders, Potato

\begin{abstract}
Post harvest management of potato under sub-tropical conditions in Jammu division was studied. The losses due to poor handling and storage are reported to be in between 40 and $50 \%$. The physiological and pathological causes observed before and during storage on potato crop revealed that $51.51 \%$ of respondents observed bruises on tubers followed by rooting (48.00\%), chilling injury (44.89\%), enlarged lenticels (42.67\%) and sprouting up to $40.89 \%$.
\end{abstract}

Damage to potato (Solanum tuberosum L., Solanaceae) can be carried out via physiological disorder. Physiological disorders reduce marketability of tubers by damaging appearance or reducing processing quality. Foliar disorders mostly limit yield, while tuber disorders can decrease the market value of the crop. Common physiological disorders of potato foliage include frost, hail, lightening, wind burn and air pollution damage. In some cases, these defects also make the tubers more susceptible to decay. Common disorders that produce symptoms outside the tuber include growth cracks, secondary growth (knobs, dumbbells, and malformed), heat sprouts, enlarged lenticels and greening. Physical damage to potatoes causes stress and leads to physiological aging of the tubers.

Careful storage loading can reduce bruising. Drops and roll down can lead to skinning and bruising (William. and Steven 2010). The objective of the present research was to study the physiological disorders observed on potato and their control in subtropical plains of Jammu.

The study was carried out during 2011 - 2012 in the sub-tropical zone of Jammu division and three districts, namely Jammu, Kathua and Samba were selected on the basis of maximum acreage under potato crop.

Seven, four and three villages from the Subdivisions of Marh, R.S. Pura and Dayalachak, respectively and one village from the Subdivision Samba were selected on the basis of proportionality of area under potato cultivation. From each village, 15 respondents were selected randomly, making a total sample size of 225 farmers. Data were collected by interviewing the potato growers with the help of structured interview schedule. After the collection of data from the respondents, the data was analyzed with suitable statistical measure.

As evident from the data, more than half of the respondents (51.51\%) observed bruises on potato tubers followed by rotting (48.00\%), chilling injury (44.89\%), enlarged lenticels (42.67\%) and sprouting (40.89\%). Shrinkage and greening in potatoes was observed by 38.67 and 33.33 per cent respondents, respectively (Table 1.). The findings are supported by Sharma (2009), who had

*Author for correspondence: <qadrijavid2008@gmail.com>. ${ }^{1}$ Division of Extension Education, FOA, Wadura, Campus, SKUAST-Kashmir. ${ }^{2}$ Division of Post Harvest Technology-SKUAST-Kashmir. ${ }^{3}$ Division of Extension Education FOA, Wadura Campus, SKUAST-Kashmir. ${ }^{4}$ Directorate of Extension Education. SKUAST--Kashmir. 
reported that (50\%) observed bruises on potato crop and one third of the respondents, 38.13, 34.38 and 31.25 per cent observed physiological disorders like chilling injury, rotting and shrinkage were observed respectively.

Table 1. Physiological disorder of potato tuber before and during storage in different potato growing zones of Jammu $\mathbf{n}=225$.

\begin{tabular}{|c|c|c|c|c|c|}
\hline \multirow[b]{2}{*}{$\begin{array}{l}\text { Physiological } \\
\text { disorder before } \\
\text { and during storage }\end{array}$} & \multicolumn{4}{|c|}{ Subdivision-wise percentage of respondents } & \multirow{2}{*}{$\begin{array}{l}\text { Overall \% age of } \\
\text { Respondents from } \\
\text { all sub divisions }\end{array}$} \\
\hline & $\begin{array}{c}\text { Marh } \\
(n=105)\end{array}$ & $\begin{array}{l}\text { R S Pura } \\
(n=60)\end{array}$ & $\begin{array}{l}\text { Dayalachak } \\
(n=45)\end{array}$ & $\begin{array}{l}\text { Samba } \\
(n=15)\end{array}$ & \\
\hline Bruises & $\begin{array}{c}(46.67) \\
49\end{array}$ & $\begin{array}{c}(51.67) \\
31\end{array}$ & $\begin{array}{c}(60.00) \\
27\end{array}$ & $\begin{array}{c}(53.33) \\
8\end{array}$ & $\begin{array}{c}(51.11) \\
115\end{array}$ \\
\hline Shrinkage & $\begin{array}{c}(40.00) \\
42\end{array}$ & $\begin{array}{c}(41.67) \\
25\end{array}$ & $\begin{array}{c}(31.11) \\
14\end{array}$ & $\begin{array}{c}(40.00) \\
6\end{array}$ & $\begin{array}{c}(38.67) \\
87\end{array}$ \\
\hline Sprouting & $\begin{array}{c}(38.09) \\
40\end{array}$ & $\begin{array}{c}(46.67) \\
28\end{array}$ & $\begin{array}{c}(42.22) \\
19\end{array}$ & $\begin{array}{c}(33.33) \\
5\end{array}$ & $\begin{array}{c}(40.89) \\
92\end{array}$ \\
\hline Chilling injury & $\begin{array}{c}(37.14) \\
39\end{array}$ & $\begin{array}{c}(58.33) \\
35\end{array}$ & $\begin{array}{c}(44.44) \\
20\end{array}$ & $\begin{array}{c}(46.67) \\
7\end{array}$ & $\begin{array}{c}(44.89) \\
101\end{array}$ \\
\hline Greening & $\begin{array}{c}(33.33) \\
35\end{array}$ & $\begin{array}{c}(35.00) \\
21\end{array}$ & $\begin{array}{c}(35.55) \\
16\end{array}$ & $\begin{array}{c}(20.00) \\
3\end{array}$ & $\begin{array}{c}(33.33) \\
75\end{array}$ \\
\hline Enlarged lenticels & $\begin{array}{c}(43.80) \\
46\end{array}$ & $\begin{array}{c}(40.00) \\
24\end{array}$ & $\begin{array}{c}(40.00) \\
18\end{array}$ & $\begin{array}{c}(53.33) \\
8\end{array}$ & $\begin{array}{c}(42.67) \\
96\end{array}$ \\
\hline Rooting & $\begin{array}{c}(42.85) \\
45\end{array}$ & $\begin{array}{c}(53.33) \\
32\end{array}$ & $\begin{array}{c}(53.33) \\
24\end{array}$ & $\begin{array}{c}(46.67) \\
7\end{array}$ & $\begin{array}{c}(48.00) \\
108\end{array}$ \\
\hline
\end{tabular}

"p value $0.498,0.128,0.090,0.503$.

Since the calculated p-value is more than 0.05 hence the psychological disorder is independent of the purposively selected potato growing Subdivisions of Marh, R.S. Pura, Dayalachak and Samba of Jammu, Kathua and Samba districts of Jammu division

The commonly found physiological disorders in potato include bruises, chilling injury, enlarged lenticels, sprouting, greening, rotting and shrinkage. Losses caused by bruising are difficult to measure while potatoes are being harvested. Bruises reduce economic value of potato, increases shrinkage in storage as well as cause direct loss. Do not lift tubers if the soil is very dry/hard and leave tubers on the soil surface for two to three hours after lifting so that the skins dries and handle the tubers carefully to avoid any bruises damage. Chilling injury or low temperature may occur in the field or in storage when potatoes are exposed to temperatures slightly above freezing. Injuries range from grey to black patches in the tuber tissue to a brown discoloration of the vascular ring and may be controlled by storing tubers in dry, cool conditions at $2-4^{\circ} \mathrm{C}$. The lenticels may become enlarged when tubers are exposed for prolonged periods to highly wet soil. Sprouting leads to the tuber formation sometimes' even causing the tuber to split and to form small tubers internally. Storage of tubers above $16^{\circ} \mathrm{C}$ affects physiologicall age of the tuber. Besides low concentrations of a chemical sprout inhibitor (chlorpropham) causes internal sprouting. Low temperature storage and use of potato sprout inhibitors like chlorpropham, maleic hydrazide etc., may help to control sprouting (Lewis et.al 1997). Potato tuber exposure to sunlight or artificial light in storage causes tuber greening. Tuber greening may be associated with the formation of one or more bitter tasting, poisonous glycoalkaloids. For controlling greening we should not expose tubers to direct sunlight or high temperatures or freezing temperatures. The 
rotting symptoms of tubers include discolored patches on the skin and after cutting the tuber open reveals a reddish-brown, granular rot, often just below the skin.. If rots are present dispose of affected tubers, sorting and removal of rotted and damaged tubers before and after storage may help to control rotting. During shrinkage, the stored potatoes lose weight by shedding water to the surrounding air (transpiration) through the physiological respiration process. The transpirational water loss can be greatly reduced by maintaining a high relative humidity.

\section{Acknowledgement}

Author is thankful to the Division of Agricultural Extension Education, SKUAST-Jammu for providing necessary guideline for the study.

\section{References}

Lewis MD, Thornton MK and Kleinkopf GE 1997. Commercial application of CIPC sprout inhibitor to storage potatoes. Curr. Info. Ser No. 059. Univ. of Idaho.

Sharma M 2009. Adoption of recommended farm practices of major vegetable. Crops in Punjab. Ph.D. thesis. Punjab Agricultural University, Ludhiana. pp.1-163.

William HB and Steven BJ 2010.Commercial potato production in North America, Amer. Potato J. 57: 73-77 and USDA. Hand-book 267 by the Extension Section of Potato Association of America. 